\title{
Histiocytic and dendritic reticulum cells shown by a zinc iodide-osmium technique
}

\author{
J CROCKER, MARY HOPKINS
}

From the Histopathology Department, East Birmingham Hospital, Bordesley Green East, Birmingham, B9 $5 S T$

SUMMARY Structures corresponding to histiocytic and dendritic reticulum cells have been shown in human tonsillar tissue, "reactive" lymph nodes and spleens by means of a zinc iodide-osmium technique. These cell types have been shown in various locations in these tissues using paraffin and resin embedded sections produced after fixation/staining of the tissue in zinc iodide-osmium. The quality of morphology attained by this procedure is much improved compared with the demonstration of the two cell types by means of $\alpha$-naphthyl acetate esterase reactions performed on frozen sections. The zonal architecture of the lymphoid follicle is emphasised by this technique. In lymph nodes, sinus lining cells are also shown. Lymphoid cells, polymorphs, fibroblasts, and endothelial cells are negative with the zinc iodide-osmium method. In addition, interdigitating cells are not stained. The results of this procedure are compared with those of other methods for the demonstration of histiocytic and dendritic reticulum cells.

Histiocytic and dendritic reticulum cells may be shown in tissue sections by various means. Both cells contain non-specific esterase-for example, $\alpha$-naphthyl acetate esterase-although this is much weaker in dendritic reticulum cells than histiocytic reticulum cells. ${ }^{2}$ Dendritic reticulum cells also possess surface 5 '-nucleotidase, but the demonstration of this enzyme usually requires unfixed frozen sections, ${ }^{12}$ whereas fixed frozen sections are generally used for the $\alpha$-naphthyl acetate esterase method. Various immunohistochemical markers, such as muramidase, ${ }^{23} \alpha_{1}$-antitrypsin, ${ }^{4}$ and cathepsin $\mathrm{B},{ }^{25}$ are present in histiocytic reticulum cells but appear to be absent from dendritic reticulum cells; however, surface immunoglobulin has recently been shown on the surface of the latter cells in frozen sections. ${ }^{6}$ Thus, in general, dendritic reticulum cells are not readily shown with techniques using paraffin sections.

The Langerhans' cells of the epidermis, which are believed to be related to the macrophage series of cells, have been shown at both the light microscope and ultrastructural level by means of zinc iodideosmium staining. ${ }^{7}$ We have investigated the usefulness of this technique for demonstrating histiocytic reticulum cells and dendritic reticulum cells in

Accepted for publication 19 February 1984 human palatine tonsils, lymph nodes, and spleens.

\section{Material and methods}

\section{TISSUES STUDIED}

Seven human palatine tonsils, five "reactive" lymph nodes, and three normal spleens removed surgically were cut into $2 \mathrm{~mm}$ thick slices with a degreased razor blade immediately after excision. The slices were promptly dropped into the zinc iodide-osmium fixative.

The tonsils had been removed electively for recurrent sore throats. In two cases the lymph nodes were specimens draining carcinomas (but not infiltrated) and in three cases came from patients with toxoplasmosis infection. The spleens had been removed incidentally at gastrectomy.

\section{ZINC IODIDE-OSMIUM FIXATIVE AND \\ PROCESSING}

One of the zinc iodide-osmium methods of Rodriguez and Caorsi ${ }^{7}$ was adopted. The zinc iodideosmium mixture acts as simultaneous fixative and stain and was made up as follows: (a) $12 \mathrm{~g}$ zinc powder and $5 \mathrm{~g}$ mercuric iodide were dissolved in $200 \mathrm{ml}$ of $0.2 \mathrm{M}$ sodium barbiturate- $\mathrm{HCl}$ buffer, $\mathrm{pH} 7 \cdot 4 ;(b)$ the mixture was shaken thoroughly and filtered; and $(c)$ immediately before use, three parts 
of the mixture were added to one part of $2 \%$ osmic acid.

Tissue slices were fixed in the zinc iodide-osmium for $18 \mathrm{~h}$ at $4^{\circ} \mathrm{C}$, then dehydrated, cleared, and embedded in paraffin wax. Sections were then cut at 3-4 $\mu \mathrm{m}$, counterstained with Mayer's haemalum, and mounted in synthetic medium.
In addition, stained slices were dehydrated in acetone at $20^{\circ} \mathrm{C}$ and embedded in "Transmit" resin and sections were cut at 1-3 $\mu \mathrm{m}$ thickness, then counterstained and mounted as above.

As controls, fresh tissues were placed in osmic acid alone, at $4^{\circ} \mathrm{C}$ for $18 \mathrm{~h}$, before embedding, in the absence of the zinc iodide mixture.

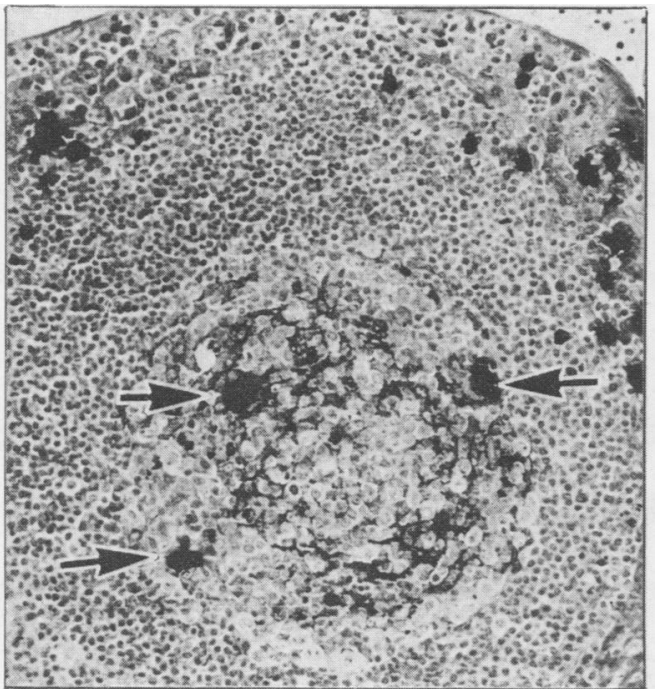

Fig. 1

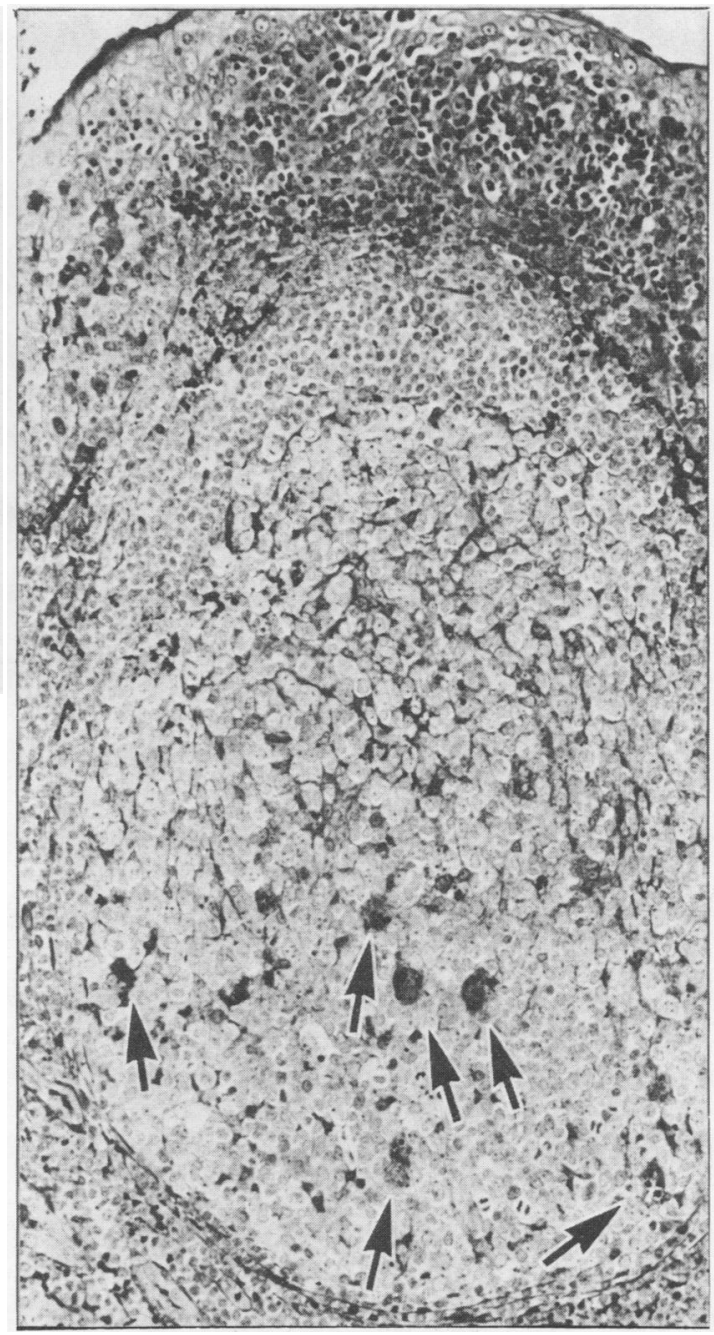

Fig. 2

Fig. 1 Section through basal to middle zones of tonsillar lymphoid follicle. Centrally, there are three histiocytic reticulum cells (arrows) with a superimposed meshwork pattern of dendritic reticulum cell processes. The crypt epithelium is shown in the upper part of the figure and includes darkly stained histiocytic reticulum cells. Zinc iodide-osmium procedure, haemalum counterstain: Paraffin wax embedded section. $\times 110$

Fig. 2 Longitudinal section through an entire tonsillar lymphoid follicle. In the basal zone large, deeply stained histiocytic reticulum cells are present (arrows). In the middle zone there is a striking network of dendritic reticulum cell processes and in the mantle zone cap only very fine dentrites are seen. Zinc iodide-osmium procedure, haemalum counterstain. Transmit resin embedded section. $\times 200$ 


\section{Results}

TONSILS

Lymphoid follicles

In these areas histiocytic reticulum cells (including "tingible body macrophages") were stained an intense black. On high power examination, the reac- tion product was seen to be cytoplasmic and was coarsely granular or occupied vacuoles. At the basal area (zone A) of the follicle, where centroblasts were numerous, these cells were especially common, becoming progressively fewer in the middle area (zone B) and absent from the upper area (zone C), nearest to the crypt epithelium (Figs. 1 and 2).
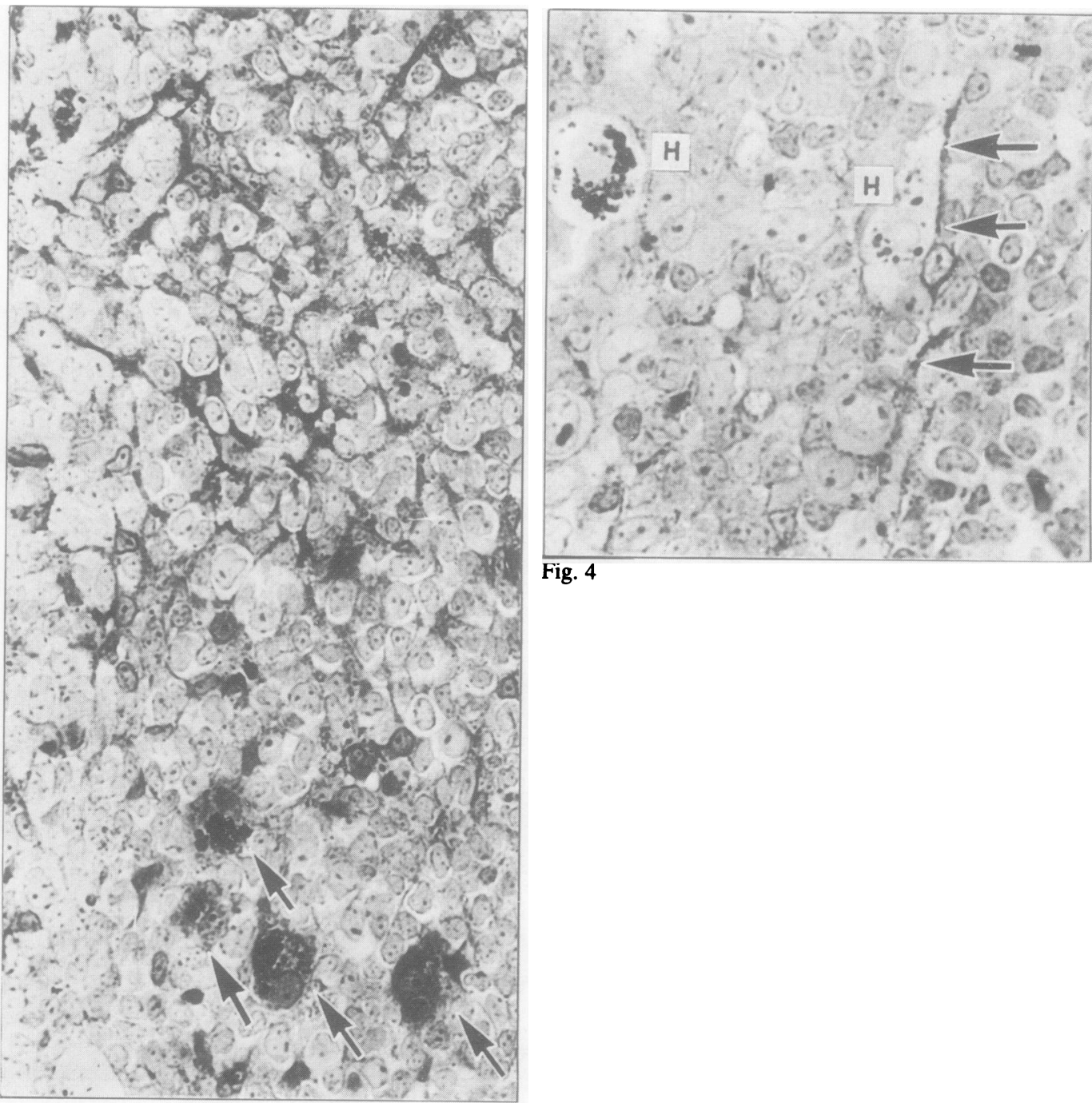

Fig. 4

Fig. 3

Fig. 3 High power photograph of follicle centre. The upper two thirds of the figure (zone B) shows very numerous interlacing dendritic processes. In the lower third of the field (zone $A$ ) there are four histiocytic reticulum cells (arrows). Zinc iodide-osmium procedure. haemalum counterstain. Transmit resin embedded section. $\times 400$

Fig. 4 High power view of periphery of germinal follicle centre. Two histiocytic reticulum cells are seen $(H)$ and running part circumferentially is a dendritic reticulum cell with characteristic nucleus and long zinc iodide-osmium positive processes (arrows). Zinc iodide-osmium procedure, haemalum counterstain. Transmit resin embedded section. $\times 600$ 
In contrast, dendritic reticulum cells, which were also stained intensely by the zinc iodide-osmium method, were especially common in zone B, where centrocytes abound (Fig. 3). Their cell body cytoplasm and dendritic processes stained with a finely granular pattern and, in thicker paraffin and resin sections, could be seen to ramify in a complex fashion in the germinal centres. These processes were often arranged part circumferentially at the periphery of the follicles (Fig. 4). Finer dendrites were present on the dendritic reticulum cells of zone C.
Other cells of the follicles, such as centroblasts, centrocytes, lymphocytes, and endothelial cells, were all consistently zinc iodide-osmium negative.

\section{Interfollicular areas}

Lymphoid and endothelial cells in these areas were zinc iodide-osmium negative. Occasional zinc iodide-osmium positive histiocytic reticulum cells were present, but cells with dendritic processes (that is, interdigitating cells) were not evident. High endothelial vessels and fibroblasts were negative (Fig. 5).

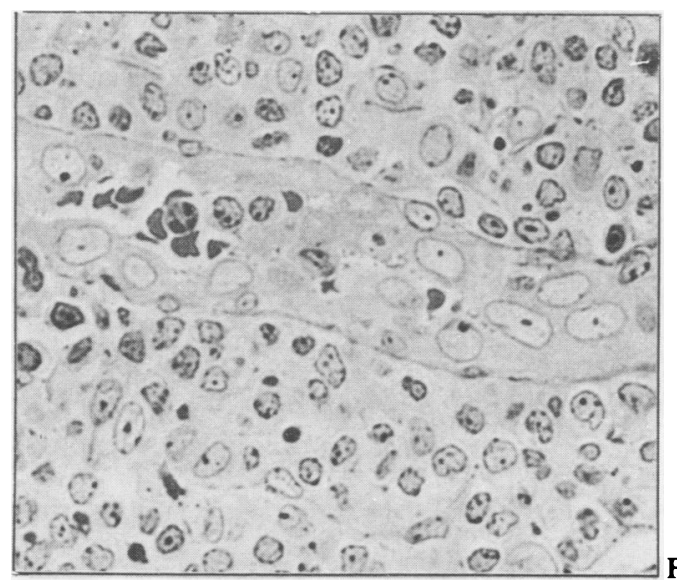

Fig. 5

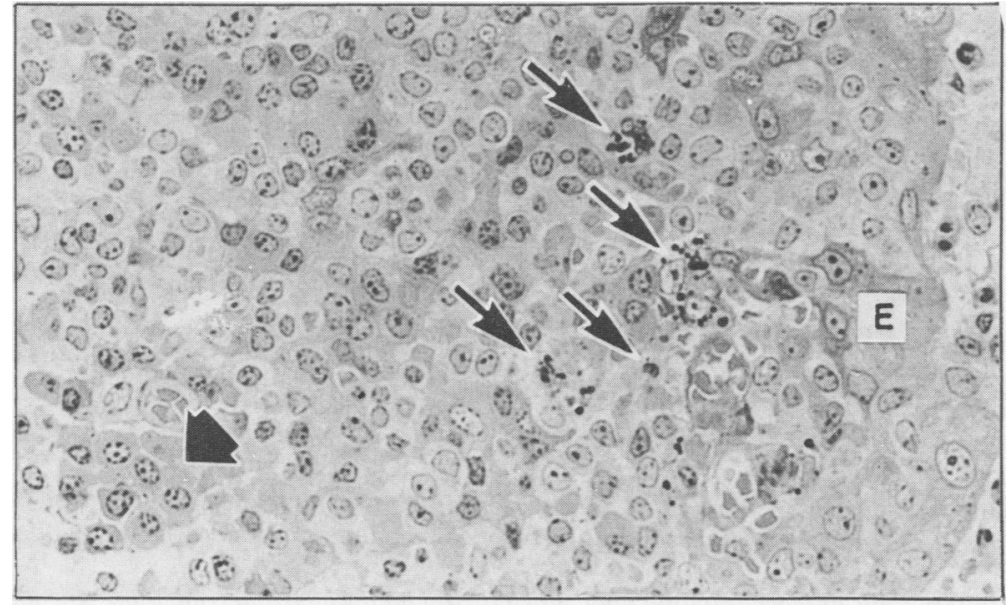

Fig. 6

Fig. 5 Interfollicular area showing zinc iodide-osmium negative high endothelium vessel. No positive cells are present in this figure. Zinc iodide-osmium procedure, haemalum counterstain. Transmit resin embedded section. $\times 400$

Fig. 6 Zinc iodide-osmium negative crypt epithelium $(E)$ within and beneath which there are scattered histiocytic reticulum cells (thin arrows). A cluster of negative Marschalko plasma cells is present (broad arrows). Zinc iodide-osmium procedure, haemalum counterstain. Transmit resin embedded section. $\times 300$ 


\section{Crypt epithelium}

The epithelial cells of the tonsillar crypts and the squamous pharyngeal epithelium were negative with the zinc iodide-osmium method. In contrast, numerous strongly positive histiocytic reticulum cells were present within the basket like meshwork of the crypt epithelium (Fig. 6). Dendritic reticulum cells were not found in this region. Occasional Marschalko type plasma cells were present and were usually zinc iodide-osmium negative, but very occasionally appeared to possess three or four minute "dots" of reaction product in the cytoplasm. No other positively staining cells were found in or adjacent to the crypt epithelium.

Granulomatous foci were present in one tonsil; here, the histiocytic reticulum cells and multinucleate giant cells were intensely stained (Fig. 7).
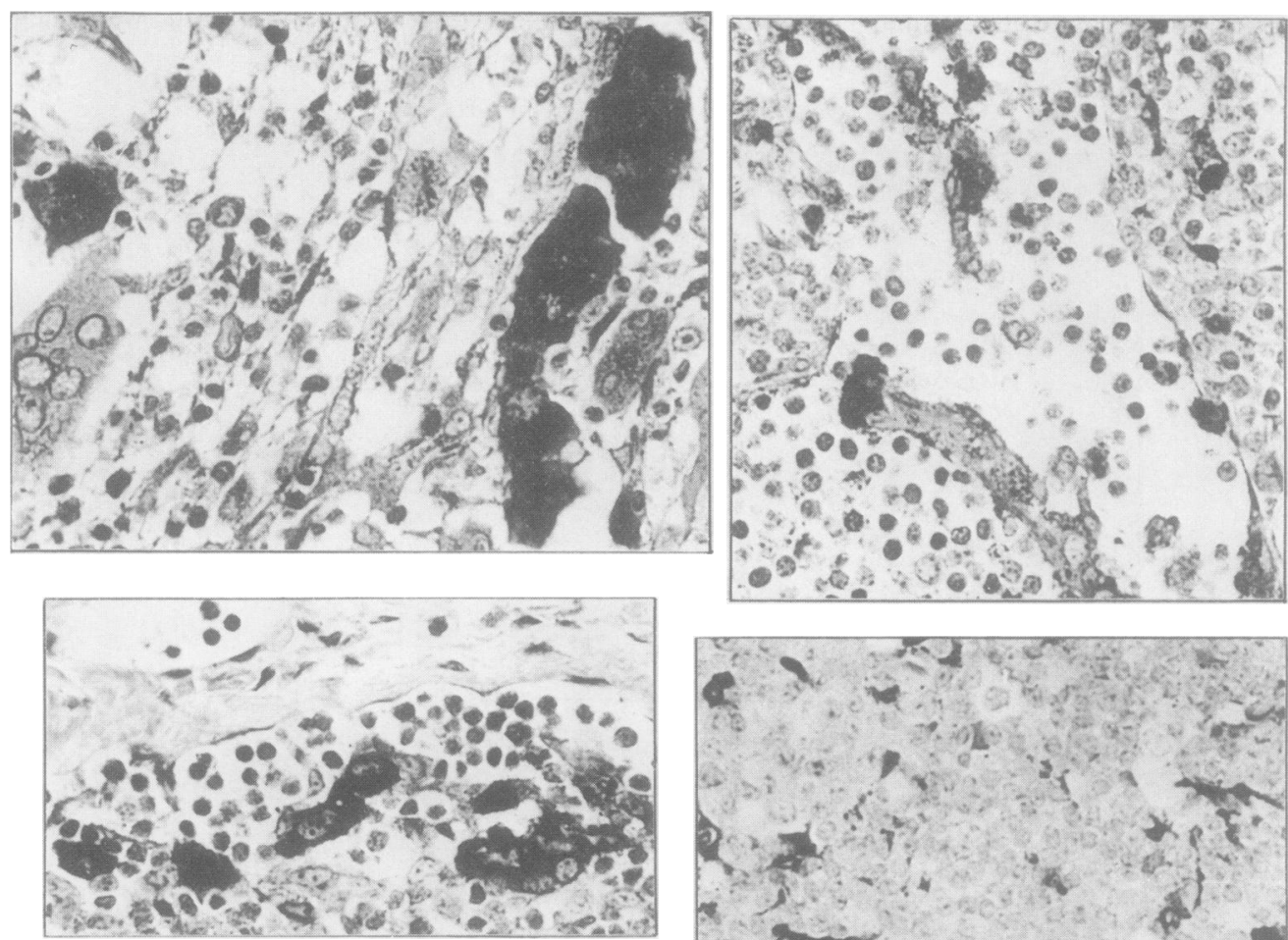

Fig. 7 (top left)

Fig. 8 (top right)

Fig. 9 (bottom left)

Fig. 10 (bottom right)

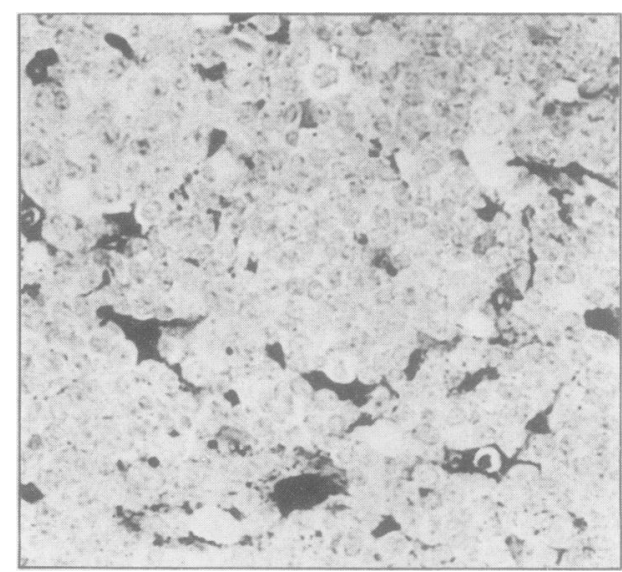

Fig. 7 Granulomatous region in tonsil. Multinucleate giant cells are intensely positive (with one being less strongly stained). Zinc iodide-osmium procedure, haemalum counterstain. Paraffin wax embedded section. $\times 350$

Fig. 8 Medullary sinus of reactive lymph node, lined by (on both walls) and containing zinc iodide-osmium positive sinus lining cells. Zinc iodide-osmium procedure, haemalum counterstain. Paraffin wax embedded section. $\times 280$

Fig. 9 Marginal sinus of lymph node, with zinc iodide-osmium positive sinus lining cells only on inner aspect (lower side of sinus in figure). Zinc iodide-osmium procedure, haemalum counterstain. Paraffin wax embedded section. $\times 260$

Fig. 10 Sinus lining cells of splenic red pulp staining positively. Zinc iodide-osmium procedure, haemalum counterstain. Paraffin wax embedded section. $\times 200$ 


\section{LYMPH NODES}

\section{Lymphoid follicles}

The staining pattern was identical to that in the tonsils. Histiocytic reticulum cells were intensely stained with a coarsely granular appearance, and dendritic reticulum cells possessed positively stained long slender processes. A distinct zonality was again shown.

\section{Interfollicular areas}

Again, the appearances were the same as those in the tonsils. Occasional positive histiocytic reticulum cells were evident, but structures corresponding to interdigitating cells were not stained.

\section{Lymphatic sinuses}

The sinus lining cells of the marginal, intermediate, and medullary sinuses were stained positively and in a granular fashion by the zinc iodide-osmium reaction (Fig. 8). Both the luminal (reticular) and lining (littoral) cells were stained, although there was no positivity on the outer aspect of the marginal sinuses (Fig. 9).

\section{SPLEENS}

White pulp

The white pulp lymphoid follicles contained positive histiocytic and dendritic reticulum cells disposed in a similar fashion to the arrangement in tonsils and lymph nodes. However, a less definite polarity was seen. The histiocytic reticulum cells of the white pulp marginal zone were also stained.

\section{Red pulp}

The sinus lining cells were strongly zinc iodideosmium positive and possessed fine branching processes (Fig. 10). Other cells in the red pulp were not stained.

\section{CONTROLS}

Fixation in osmic acid, in the absence of zinc iodide, resulted in an absence of staining in all areas and cells of the tissues.

\section{Discussion}

There are numerous techniques for demonstrating histiocytic reticulum cells in tissue sections. These range from observation of conventional preparations (where many such cells are almost certainly overlooked), to histochemical methods for lysosomal or other hydrolytic enzymes, such as non-specific esterases, acid phosphatase, and $\beta$-glucuronidase, ${ }^{\prime 2}$ and immunohistochemical staining for macromolecules present in high concentrations in these cells. The latter substances include $\alpha_{1}$-antitrypsin ${ }^{4}$ and the enzymes muramidase ${ }^{134}$ and cathepsin B. ${ }^{58}$

Dendritic reticulum cells, however, are more difficult to show in sections at the optical microscope level, and it is partly for this reason that the present study was undertaken. These cells, whose relation to histiocytic reticulum cells is poorly understood, appear to have a critical role in antigen "handling" in germinal follicle centres, ${ }^{910}$ and at the ultrastructural level they can be seen to possess highly complex dendritic processes and surface 5'-nucleotidase." They appear to be restricted to follicle centres. ${ }^{112}$ The technique for $5^{\prime}$-nucleotidase demonstration is somewhat capricious ${ }^{2}$ and, at the light microscope level, requires frozen section methods, which inevitably result in less than ideal morphological detail.' 2 Simultaneous azocoupling techniques, applied to fixed frozen sections, show weak $\alpha$-naphthyl acetate esterase positivity in dendritic reticulum cells, although acid phosphatase (which, like $\alpha$-naphthyl acetate esterase, is strongly positive in histiocytic reticulum cells) is absent from dendritic reticulum cells. ${ }^{12}$

An alternative approach to the demonstration of dendritic reticulum cells (and some histiocytic reticulum cells) was adopted by Curran and Jones, who applied the Marshall metalophil reaction to paraffin sections of palatine tonsils and "reactive" lymph nodes. ${ }^{613}$ In both of these studies, performed at the optical microscope level, the zonal nature of the lymphoid follicle was shown by a transition from the basal to upper zone ( $A$ to $C$ ), with increasing numbers of metalophil dendritic reticulum cells; less strongly staining histiocytic reticulum cells were common in zone A but almost absent at higher levels. In one of these studies, ${ }^{13}$ dendritic reticulum cells were also shown by the presence of surface immunoglobulin which outlined their dendritic processes. A similar zonality is also seen in benign follicles by means of, for example, the $\alpha$-naphthyl acetate esterase reaction but is absent from malignant lymphoid follicles. ${ }^{2}$ The reaction requires frozen section methods, however, and the zinc iodide-osmium method, with its potentially excellent morphological capability, is well suited to the demonstration of lack or presence of zonality.

The structured nature of reactive follicles has been emphasised elsewhere, ${ }^{14}$ histiocytic reticulum cells being seen in the basal, centroblast rich area and dendritic reticulum cells being common in the middle and upper areas, where centrocytes abound. It is of interest in this context that branching $\alpha$-naphthyl acetate esterase positive cells are seen more in centrocytic malignant lymphomas than in their centroblastic counterpart. ${ }^{15}$

The presence of zinc iodide-osmium positive cells 
within the tonsillar crypt epithelium is a constant finding, the importance of which is uncertain, although these cells may be concerned with antigen "handling" in this site. ' Numerous histiocytic reticulum cells have been previously noted in this site, by means of both enzyme histochemistry ${ }^{2}$ and transmission electron microscopy. ${ }^{16}$ In the latter study, Birbeck granules were not described in these cells, and it thus appears that most, if not all of them, are histiocytic reticulum cells. Some could, of course, be Langerhans' cells. In contrast to the $\alpha$-naphthyl acetate esterase or acid phosphatase reactions, ${ }^{12}$ lymphocytes do not show punctate zinc iodide-osmium activity.

The findings in lymph nodes mimick those obtained in fixed frozen sections stained for $\alpha$-naphthyl acetate esterase activity. ${ }^{217}$ The littoral and reticular sinus lining cells are strongly positive for $\alpha$-naphthyl acetate esterase and this pattern, including a lack of activity on the outer aspect of marginal sinuses, is identical to that obtained with the zinc iodide-osmium procedure. Immunohistochemical staining of the sinuses for the enzyme cathepsin B shows the same features. ${ }^{5}$ Similarly, the pattern of staining of histiocytic and dendritic reticulum cells in lymph node follicle centres is the same with both techniques, although much improved morphology is attainable with the zinc iodide-osmium reaction. The staining of sinus lining cells in the spleens was striking and constant, although, of course, we cannot comment on the functional relation of these cells to histiocytic or dendritic reticulum cells.

The zinc iodide-osmium method was first described by Maillet ${ }^{18}$ and has been applied to the demonstration of epidermal Langerhans' cells by light and electron microscopical techniques.? ${ }^{19}$ The relation between Langerhans' and other cells of the "mononuclear phagocyte system" is uncertain; ${ }^{20}$ like the interdigitating cells of the $T$ cell regions, they possess surface cation dependent adenosine triphosphatase, but reports concerning their phagocytic capability vary. ${ }^{2021}$ Ultrastructurally, Langerhans' cells possess characteristic cytoplasmic structures, named Birbeck granules, although these are probably not fully specific to these cells.?

The current findings are of importance in view of the contentious relation between Langerhans' cells and "reticulum cells." In terms of zinc iodideosmium positivity, similarities clearly exist between Langerhans' cells, dendritic and histiocytic reticulum cells; however, shared properties do not necessarily imply ontological similarity. Indeed, the presence of surface ATPase on interdigitating cells and Langerhans' cells does not correspond with the zinc iodide-osmium negativity of the former com- pared with the positivity of the latter, since struc- $\frac{0}{\vec{*}}$

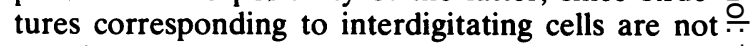
seen in T dependent areas of lymphoid tissues using $\overrightarrow{\vec{S}}$ of zinc iodide-osmium method.

Several monoclonal antisera have been used to study dendritic cells: these include antibodies to $C 3 \mathrm{~b} \frac{\bar{\sigma}}{\bar{\omega}}$ receptor (which also stain histiocytic reticulum cells $\frac{\vec{\sigma}}{\vec{\phi}}$ and, probably, some mantle zone lymphoid cells); $\propto$ commercial preparations against DRC-1 (which is $\%$ more specifically active with dendritic reticulum $\overrightarrow{0}$ cells) and against HLA-DR or Ia (which labels B cell follicles, interdigitating cells, Langerhans' cells, $\vec{\sim}$ endothelial cells, and some histiocytic reticulum $\frac{}{\circ}$ cells and some $\mathrm{T}$ cells).$^{14}$ More recently, Naiem et ${ }^{\text {? }}$ $a l^{22}$ have described a monoclonal antiserum (R4/ 23) which appears to be remarkably specific. With regard to Langerhans' cells themselves, these can be $\mathbb{N}$ shown to possess $\mathrm{Fc}-\mathrm{IgG}$ and $\mathrm{C} 3$ receptors, ${ }^{23}$ possess $\mathrm{Ia}^{24}$ and react with OKT6. ${ }^{25}$ They also label with antiserum to $S-100,,^{25}$ which also stains interdigitat- $\vec{c}$ ing cells. ${ }^{27}$

Thus there are numerous monoclonal antisera ${ }^{\Phi}$ available for the demonstration of reticulum cells. $\overrightarrow{0}$ Manifestly, many of these antibodies are not fully specific. In addition, they require frozen section methods and the morphology attainable is not as satisfactory as that possible with the zinc iodideosmium reaction, where, although fresh material is initially a prerequisite, subsequent paraffin or plastic $\mathbb{Q}$ embedding affords excellent section quality.

We are grateful to Mrs Ruth Fry for her painstaking secretarial work and to Mr MJ Chard for expert? photographic assistance. Mr RM Simons, Mr PM Shenoi, and Mr K Pearman kindly cooperated with? the supply of surgical material.

\section{References}

' Crocker J. The enzyme histochemistry of lymphoid and nonlymphoid cells of the human palatine tonsil: a basis for theo
study of lymphomas. J Pathol 1981;134:81-95. ${ }^{2}$ Crocker J. The enzyme histochemistry of lymphomas. University

${ }^{3}$ Mason DY, Taylor CR. The distribution of muramidase $\mathrm{O}$ (lysozyme) in human tissues. J Clin Pathol 1975;28:124-32. Nิ

4 Isaacson P, Jones DB, Millward-Sadler GH, Judd MA, Payne S. Alpha-1-antitrypsin in human macrophages. J Clin Pathol 1981;34:928-90.

${ }^{5}$ Crocker J, Burnett D, Jones EL. Immunohistochemical demonstration of cathepsin $B$ in the macrophages of benign and malignant lymphoid tissues. $J$ Pathol 1984;142:87-94.

- Curran RC, Gregory J, Jones EL. The distribution of immuno-globulin and other plasma proteins in human reactive lymph nodes. J Pathol 1982;135:307-32.

7 Rodriguez EM, Caorsi I. A second look at the ultrastructure of $\frac{\text { }}{\mathscr{D}}$ the Langerhans cell of the human epidermis. J Ultrastruc Res 0 1978;65:279-95.

${ }^{8}$ Burnett D, Crocker J, Vaughan ATM. Synthesis of cathepsin $\mathrm{B}_{\Omega}$ 
by cells derived from the HL60 promyelocytic leukaemia cell line. J Cell Physiol 1983;115:249-54.

' Nossal GJV, Abbot A, Mitchell J, Lummus Z. Antigens in immunity. XV. Ultrastructural features of antigen capture in primary and secondary lymphoid follicles. J Exp Med 1968;127:277-90.

10 Veerman AJP, van Rooijen N. Lymphocyte capping and lymphocyte migration as associated events in the in vivo antigen trapping process. An electron-microscopic autoradiographic study in the spleen of mice. Cell Tiss Res 1975;161:211-7.

" Lennert K. Malignant lymphomas other than Hodgkin's disease. New York: Springer-Verlag, 1978:59-65.

12 Heusermann U, Schroeder L, Zurborn KH, Stutte HJ. Structure and function of stroma cells in lymphoid tissues. In: Goos M, Christophers E, eds. Lymphoproliferative diseases of the skin. New York: Springer-Verlag, 1982:25-33.

${ }^{13}$ Curran RC, Jones EL. The lymphoid follicles of the human palatine tonsil. Clin Exp Immunol 1978;31:251-9.

${ }^{14}$ Lennert K, Stein H. The germinal centre: morphology, histochemistry and immunohistology. In: Goos M, Christophers E, eds. Lymphoproliferative diseases of the skin. New York: Springer-Verlag, 1982:3-15.

${ }^{15}$ Crocker J, Jones EL, Curran RC. The form factor of alphanaphthyl acetate esterase-positive cells in non-Hodgkin's lymphomas and reactive lymph nodes. J Clin Pathol 1983;36:303-6.

${ }^{16}$ Howie AJ. Scanning and transmission electron microscopy on the epithelium of human palatine tonsils. J Pathol 1980;130:91-8.

17 Crocker J, Williams Mary. An enzyme histochemical study of the sinuses of reactive lymph nodes. J Pathol 1984;142:31-8.

${ }_{18}$ Maillet M. La technique de Champy a Posmium iodure de potassium et la modification de Maillet à l'osmium-iodure de zinc. Trab Inst Cajal Invest Biol 1962;54:1-36.

${ }^{19}$ Niebauer G, Krawczyk WS, Kidd RL, Wilgram CF. Osmium zinc iodide reactive sites in the epidermal Langerhans cell. J Cell

\section{Biol 1969;43:80.}

${ }^{20}$ Stingl G, Wolff $\mathrm{K}$. Origin and functions of Langerhans cells and their role in disease. In: Goos M, Christophers E, eds. Lymphoproliferative diseases of the skin. New York: SpringerVerlag, 1982:34-40.

${ }^{21}$ Wolff $\mathrm{K}$, Schreiner E. Uptake, intracellular transport and degradation of exogenous protein by Langerhans cells. An electron microscopic cytochemical study using peroxidase as tracer substance. J Invest Dermatol 1970;54:37-47.

${ }_{22}$ Naiem N, Gerdes J, Abdulaziz Z, Stein H, Mason DY. Production of a monoclonal antibody reactive with human dendritic reticulum cells and its use in the immunohistological analysis of lymphoid tissue. J Clin Pathol 1983;36:167-75.

${ }^{23}$ Stingl G, Wolff-Schreiner EC, Pichler WJ, Gschnait F, Knapp W. Epidermal Langerhans' cells bear Fc and $\mathrm{C} 3$ receptors. Nature 1977;268:245-6.

${ }^{24}$ Klareskog L, Tjernlund UM, Forsum U, Peterson PA. Epidermal Langerhans' cells express Ia antigens. Nature 1977;268:248-50.

${ }^{25}$ Murphy GF, Bhan AK, Sato S, Mihm MC, Harrist TJ. A new immunologic marker for human Langerhans' cells. $N$ Engl $J$ Med 1981;304:791-2.

${ }^{26}$ Shamoto M. Langerhans' cells increase in the dermal lesions of adult T cell leukaemia in Japan. J Clin Pathol 1983;36:30711.

${ }^{27}$ Takahashi K, Yamaguchi H, Ishizaki J, Nakajima T, Kanazoto Y. Immuno-histochemical and immunoelectron microscopic localisation of S-100 protein in the interdigitating reticulum cells of the human lymph node. Virchows Arch [Cell Pathol] 1981;37:125-35.

Requests for reprints to: Dr J Crocker, Department of Histopathology, East Birmingham Hospital, Bordesley Green East, Birmingham B9 5ST, England. 